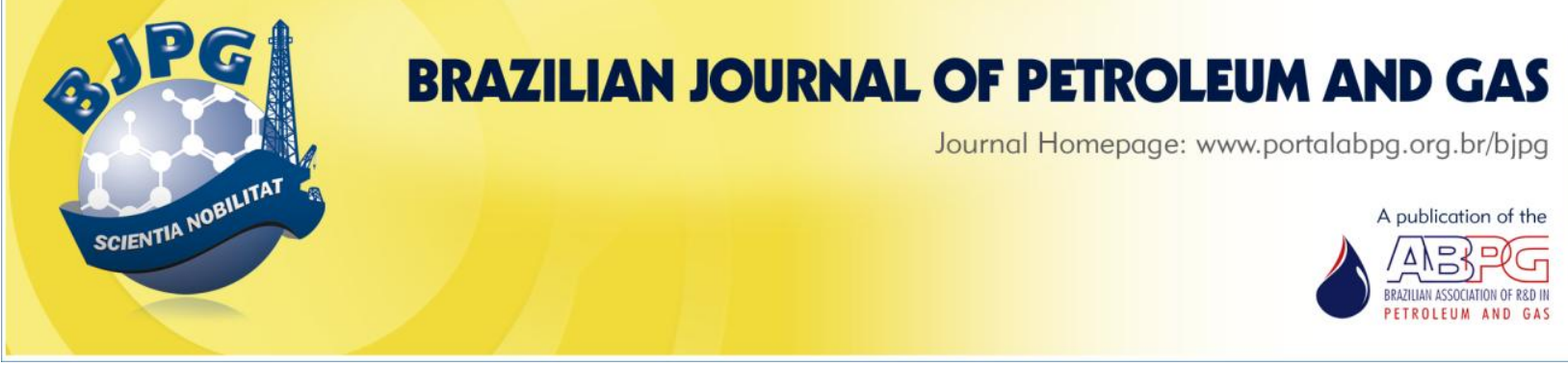

\title{
ADSORPTION OF CHROMIUM IONS ON OIL SHALE WASTE
}

\author{
a Pimentel, P. M.; ${ }^{\text {a }}$ Oliveira, R. M. P. B. ${ }^{1} ;{ }^{a}$ Melo, D. M. A.; ${ }^{\text {a, b }}$ Melo, M. A. F.;

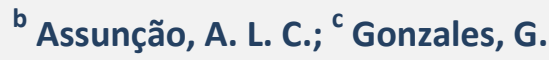 \\ a Programa de Pós-Graduação em Ciência e Engenharia de Materiais - Universidade Federal do Rio Grande do Norte \\ ${ }^{\text {b }}$ Departamento de Engenharia Química - Universidade Federal do Rio Grande do Norte
}

${ }^{\mathrm{c}}$ Centro de Pesquisas da Petrobras (CENPES)

\section{ABSTRACT}

The adsorption of chromium (III) ions onto retorted shale, a waste product of the pyrolysis of oil shale, was investigated as a function of initial $\mathrm{pH}$, temperature, and initial metal ion concentration. Adsorption experiments were carried out in a batch system and the uptake of the metallic ion was studied by using an initial concentration range of 200-500 $\mathrm{mg} \mathrm{L}^{-1}$. The pseudo-first and pseudo-second order models were used to predict the rate constants of the adsorption system. Both Langmuir and Freundlich models were used to fit the equilibrium data; however, the former resulted in best fitting. Thermodynamic parameters such as enthalpy, free energy, and entropy changes were calculated. The values of such parameters showed that $\mathrm{Cr}(\mathrm{III})$ adsorption was favored at high temperatures.

\section{KEYWORDS}

chromium (III), heavy metals, retorted shale, adsorption isotherms, wastewaters

\footnotetext{
${ }^{1}$ To whom all correspondence should be addressed.

Address: Programa de Pós-Graduação em Ciência e Engenharia de Materiais, Universidade Federal do Rio Grande do Norte, Campus Universitário, Natal (RN), Brazil

CEP: 59078-970 | Telephone: (55) 84 3215-3826 |e-mail: rosaneboliveira@gmail.com doi:10.5419/bjpg2011-0008
} 


\section{INTRODUCTION}

The presence of heavy metals in streams and lakes has been responsible for several health problems in human and other living beings. These metal ions are released to the ecosystem at elevated concentrations as a result of unregulated application and inappropriate waste-disposal practices. In particular, chromium has received considerable attention because it is a toxic metal and it does not undergo biodegradation. The main sources of water contamination with chromium ion are industrial wastewaters from leather tanning, electroplating, textile, metal processing, paint and pigments, dyeing, and steel fabrication.

Among various methods available to reduce heavy metal concentrations from wastewaters are chemical precipitation, ion-exchange, membrane filtration, and adsorption. In the last few decades, adsorption has received much consideration and has become an alternative to conventional precipitation. Adsorption is a process that involves the contact of an aqueous phase with a particulate phase, which has the ability to remove or store one or more solutes present in the solution. The use of adsorbents, e.g., activated carbon (ElShafey et al., 2002; Lyubchik et al., 2004) and ion exchange resins (Dabrowski et al., 2004) to remove trace metals from aqueous systems has been widely investigated. However, these can be considered expensive materials; thus, researchers have been encouraged to look for other adsorbent materials that are both efficient and less expensive. Several cheap and abundant materials have been studied for the adsorption of heavy metals, such as peat (Brown and Allen, 2000; Kertman et al., 1993), clays (Celis et al., 2000; Cooper et al., 2001), diatomite (Khraisheh et al., 2004), chitosan (Mckay et al., 1989), sawdust (Taty-costodes et al., 2003; Shukla et al., 2002), siderite (Erdem and Ozverdi, 2005), and spent grain (Low et al., 2000).

In the present investigation, retorted shale (RS), a waste product obtained in the pyrolysis $\left(550^{\circ} \mathrm{C}\right)$ of oil shale, was studied as a possible cost-efficient adsorbent to remove chromium ion from wastewater. Since RS holds several organic and inorganic functional groups, it has high potential for heavy metal adsorption. In addition, the technological development for the beneficial use of this material is needed, considering that oil shale is abundant in 31 countries (Al-Qodah, 2000) and
Brazil has the second largest reserve in the world and possesses the most advanced technology. The Industrialization Business Unit of Xisto Brasileira (UN-SIX) belongs to Petrobras (Brazil) and is located in the town of São Mateus do Sul, in the State of Paraná (PR). This unit falls under the largest Brazilian shale reserve, the Irati formation, where 7800 tons of shale are extracted daily, producing a solid waste called retorted shale (RS), which accounts for 80 to $90 \%$ of the raw materials used in the production process. However, the use of this waste represents one of the biggest problems associated with the industrialization of shale throughout the world.

Therefore, this study aims to evaluate the possibility of using shale waste as an adsorbent for removing $\mathrm{Cr}$ (III) ions from effluents using an adsorption technique. The investigated aspects included initial ion concentration, contact time, and $\mathrm{pH}$ of the solution.

\section{EXPERIMENTAL}

\subsection{Materials}

The retorted shale used in this study was obtained from São Mateus do Sul, State of Paraná, Southern Brazil. It was ground as received, sieved down to $75 \mu \mathrm{m}$, and used without any further treatment. All $\mathrm{Cr}$ (III) synthetic solutions were prepared dissolving chromium nitrate in deionized water.

\subsection{Methods}

\subsubsection{Equilibrium studies}

In batch adsorption experiments, a fixed mass of RS (1 g) was weighed, transferred to $120-\mathrm{mL}$ flasks, and brought into contact with $100 \mathrm{~mL}$ of a $\mathrm{Cr}$ (III) solution of desired concentration. The flasks were sealed and stirred for $7 \mathrm{~h}$ at $260 \mathrm{rpm}$ in a thermostatic shaking bath and maintained at constant temperature $\left(30,40\right.$, and $\left.50^{\circ} \mathrm{C}\right)$. The samples were taken at specific time intervals. Each experiment was repeated three times and the results are given as averages. At the end of the experiments, the adsorbent was removed by filtration through a normal filter paper and the chromium concentration in the supernatant 
solution was measured by atomic absorption spectroscopy (Varian, Espectr AA-110 model). The effect of $\mathrm{pH}$ on adsorption was studied for $5 \mathrm{~h}$ at $30^{\circ} \mathrm{C}$ and the $\mathrm{pH}$ was adjusted by adding either 1.0$\mathrm{M} \mathrm{NaOH}$ or $1.0-\mathrm{M} \mathrm{HCl}$ to the $\mathrm{Cr}(\mathrm{III})$ solution (200 mg $\left.\mathrm{L}^{-1}\right)$.

The amount of adsorbed $\mathrm{Cr}(\mathrm{III})$ and the percent adsorption (\%) were calculated as follows:

$q_{t}=\frac{\left(C_{0}-C_{t}\right) V}{W}$

Percent adsorption $(\%)=\frac{C_{0}-C_{t}}{C_{0}} \times 100$

where $q_{t}$ is the amount of $\mathrm{Cr}(\mathrm{III})$ adsorbed $\left(\mathrm{mg} \mathrm{g}^{-1}\right)$ at different times $(t), V$ is the volume of the solution (L), $W$ is the weight of the adsorbent $(\mathrm{g})$, and $C_{0}$ and $C_{t}$ are the chromium concentrations (mg $\mathrm{L}^{-1}$ ) at the beginning of the experiment and at a later time " $t$ ", respectively.

\section{RESULTS AND DISCUSSION}

\subsection{Characterization of adsorbent material}

Physical and chemical analyses of RS were carried out using conventional chemical methods and analytical techniques available. The specific surface area of RS was determined by the BET method from the adsorption-desorption isotherm of nitrogen at its liquid temperature (77 K) (NOVA 2000 BET system). Particle size was obtained in a SILAS model 1064 analyzer. The surface charge of the RS was measured at different $\mathrm{pH}^{\prime} \mathrm{s}$ using the potentiometric titration method. Adsorption kinetics assays were performed in batch reactors on a shaking incubator (TECNAL). The characteristics of the retorted shale were as follows: surface area (BET): $65.083 \mathrm{~m}^{2} \mathrm{~g}^{-1}$, density: $1.139 \mathrm{~g} \mathrm{~cm}^{-3}$, and average particle size: $19.1 \mu \mathrm{m}$. The chemical composition of the RS is shown in Table 1. In addition to the major components, the $\mathrm{RS}$ also contains $\mathrm{MnO}, \mathrm{V}_{2} \mathrm{O}_{5}, \mathrm{SrO}, \mathrm{CuO}, \mathrm{ZnO}, \mathrm{ZrO}_{2}$, $\mathrm{NiO}$, and sulfur, which account for the remaining $15.85 \%$ of the overall composition. It was observed that the chemical constituents of RS were comprised mainly by acids, bases, and amphoteric
Table 1. Chemical composition of the retorted shale.

\begin{tabular}{cc}
\hline \multicolumn{2}{c}{ Chemical analysis } \\
\hline Constituents & Weight \% \\
\hline $\mathrm{SiO}_{2}$ & 55.6 \\
$\mathrm{Al}_{2} \mathrm{O}_{3}$ & 11.4 \\
$\mathrm{Fe}_{2} \mathrm{O}_{3}$ & 8.60 \\
$\mathrm{CaO}$ & 3.50 \\
$\mathrm{~K}_{2} \mathrm{O}$ & 2.85 \\
$\mathrm{Na}_{2} \mathrm{O}$ & 1.60 \\
$\mathrm{TiO}_{2}$ & 0.60 \\
\hline
\end{tabular}

oxides, which assured the presence of active groups of mineral species and organic residues on the grain surface, suggesting good adsorption behavior.

\subsection{Effect of initial pH}

The $\mathrm{pH}$ is one the most important factors in adsorption processes, as it influences the chemistry of heavy metals solutions (i.e., hydrolysis, complexation, redox reactions, and precipitation) and strongly affects the speciation and sorption availability of heavy metals. Thus, the effect of $\mathrm{pH}$ on $\mathrm{Cr}$ (III) uptake was examined from solutions with $\mathrm{pH}$ ranging from 1 to 7 . Figure 1 shows the effect of the solution $\mathrm{pH}$ on the adsorption of $\mathrm{Cr}(\mathrm{III})$ at $30^{\circ} \mathrm{C}$, for an initial concentration of $200 \mathrm{mg} \mathrm{L}^{-1}$. It is observed that adsorption of chromium increases as the $\mathrm{pH}$ increases and decreases with decreasing $\mathrm{pH}$, since the binding sites are more protonated at low $\mathrm{pH}$ and, hence, less available to retain chromium ions. The maximum uptake of this ion was obtained at $\mathrm{pH} \sim 5$ 5.5. Above this $\mathrm{pH}$ value,

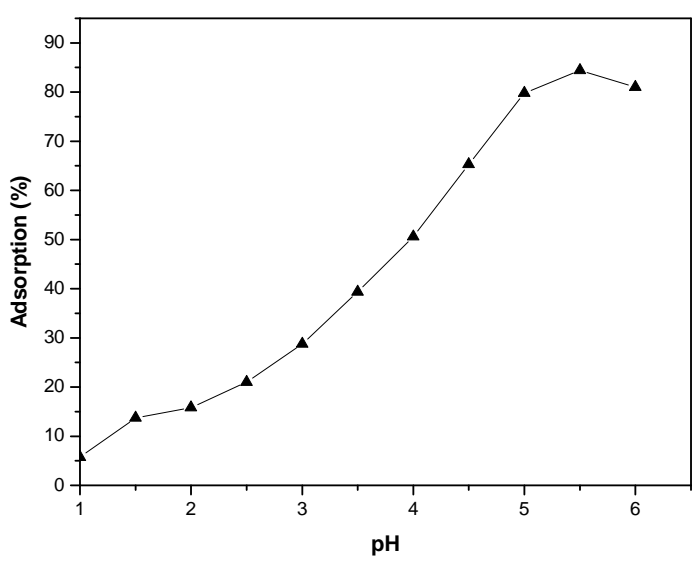

Figure 1. Effect of $\mathrm{pH}$ on $\mathrm{Cr}(\mathrm{III})$ adsorption by $\mathrm{RS}$. 
insoluble chromium hydroxide starts precipitating from the solution, making true adsorption studies impossible.

\subsection{Effect of contact time and initial concentration}

To establish an appropriate contact time between RS and $\mathrm{Cr}$ (III) ions, the adsorption capacities of the metallic ions were measured as a function of time. The experimental results for $\mathrm{Cr}$ (III) adsorption on RS for various concentrations of $\mathrm{Cr}$ (III) at $30^{\circ} \mathrm{C}$ are shown in Figure 2. It is confirmed that the higher the concentration of the solution the better the adsorption is, following an expected trend. The equilibrium time required for maximum $\mathrm{Cr}$ (III) removal is $240 \mathrm{~min}$. No further uptake was observed even after this contact time. Therefore, the isotherms were set for $7 \mathrm{~h}$ in all cases to allow sufficient time for equilibrium.

\subsection{Kinetic studies}

In order to investigate the mechanism of adsorption, the applicability of the pseudo-firstorder and pseudo-second-order adsorption models via experimental data was tested. The first-order rate expression of Lagergren (Ho and McKay, 1999) is given as:

$$
\frac{d q_{t}}{d t}=k_{1}\left(q_{e}-q_{t}\right)
$$

where $q_{e}$ and $q_{t}$ are the amounts of adsorbed $\mathrm{Cr}$ (III) $\left(\mathrm{mg} \mathrm{g}^{-1}\right)$, at equilibrium and at time $t$, respectively;

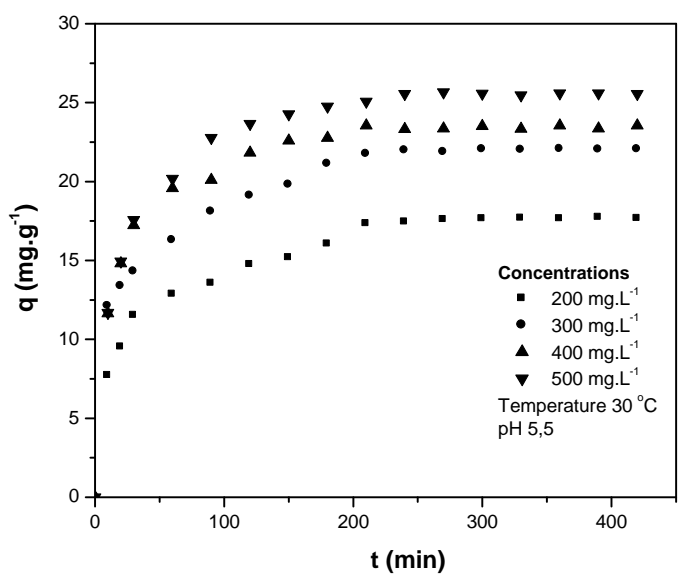

Figure 2. Effect of stirring time and initial concentration on $\mathrm{Cr}(\mathrm{III})$ adsorption by RS at $30^{\circ} \mathrm{C}$. and $k_{1}\left(\mathrm{~min}^{-1}\right)$ is the rate constant of first-order adsorption capacity (Ho and McKay, 1999). After integration and application of the boundary condition $q_{t}=0$ at $t=0$. Equation (3) gives:

$\ln \left(q_{e}-q_{t}\right)=\ln q_{e}-k_{1} t$

The slope and intercept of the plot of $\ln \left(q_{e}-q_{t}\right)$ versus $t$ was used to determine the first-order rate constant $k_{1}$.

In addition, a pseudo-second-order equation based on adsorption equilibrium capacity (Ho and McKay, 1999) may be expressed in the form of:

$\frac{d q_{t}}{d t}=k_{2}\left(q_{e}-q_{t}\right)^{2}$

where $k_{2}\left(\mathrm{~g} \mathrm{mg}^{-1} \mathrm{~min}^{-1}\right)$ is the rate constant of the pseudo-second-order. Integrating equation (5), and taking into account that the initial adsorption rate $\left(V_{o}\right)$ is $V_{0}=k_{2} q_{e}^{2}$, the following equation is obtained:

$\frac{t}{q_{t}}=\frac{1}{k_{2} q_{e}^{2}}+\frac{t}{q_{e}}$

Thus, the slope and intercept of the plot of $t / q_{t}$ versus time $t$ was used to calculate the secondorder rate constant $k_{2}$ and the parameter $q_{e}$.

Figure 3 shows the pseudo-second-order plot for $\mathrm{Cr}$ (III) adsorption at an initial concentration of $200 \mathrm{mg} \mathrm{L}^{-1}$ and different temperatures. Figure 4 shows the same plots at $30{ }^{\circ} \mathrm{C}$ and at different $\mathrm{Cr}$ (III) concentrations. The parameters calculated of both pseudo-first order and second-order rate

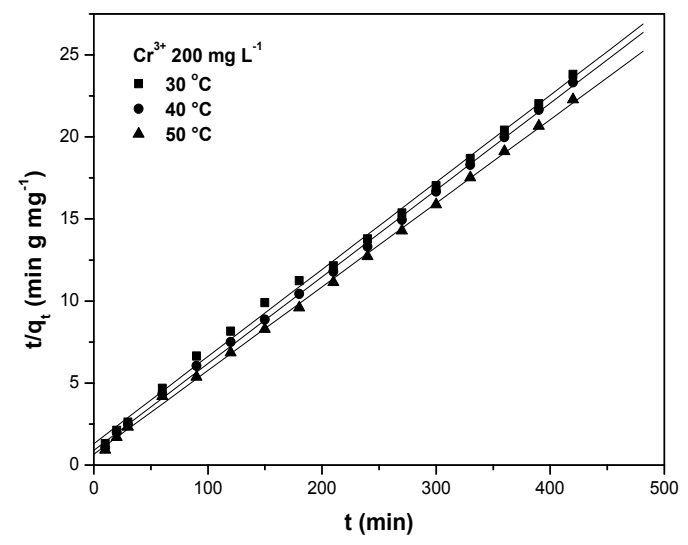

Figure 3. Pseudo-second-order plot of $\mathrm{Cr}$ (III) adsorption kinetics by RS at different temperatures and initial chromium concentration of $200 \mathrm{mg} \mathrm{L}^{-1}$. 
Table 2. Kinetic parameters of $\mathrm{Cr}$ (III) adsorption by RS at different temperatures.

\begin{tabular}{|c|c|c|c|c|c|c|c|}
\hline \multirow{2}{*}{$\begin{array}{l}C_{0} \\
\left(\mathrm{mg} \mathrm{L}^{-1}\right)\end{array}$} & \multirow{2}{*}{$\begin{array}{l}\text { Temp. } \\
\left({ }^{\circ} \mathrm{C}\right)\end{array}$} & \multicolumn{2}{|c|}{ First-order } & \multicolumn{4}{|c|}{ Second-order } \\
\hline & & $k_{1}$ & $R^{2}$ & $k_{2}$ & $\begin{array}{c}q_{e} \\
\left(\mathrm{mg} \mathrm{g}^{-1}\right)\end{array}$ & $\begin{array}{c}V_{o} \\
\left(\mathrm{mg} \mathrm{g}^{-1} \min ^{-1}\right)\end{array}$ & $R^{2}$ \\
\hline 200 & 30 & 0.0215 & 0.9808 & 0.0021 & 18.82 & 0.744 & 0.9976 \\
\hline 400 & 30 & 0.0118 & 0.9384 & 0.0016 & 23.68 & 0.897 & 0.9964 \\
\hline 200 & 40 & 0.0165 & 0.9820 & 0.0031 & 18.91 & 1.108 & 0.9991 \\
\hline 400 & 40 & 0.1360 & 0.9298 & 0.0026 & 24.38 & 1.545 & 0.9972 \\
\hline 200 & 50 & 0.0199 & 0.9822 & 0.0040 & 19.61 & 1.538 & 0.9992 \\
\hline 400 & 50 & 0.0095 & 0.9675 & 0.0030 & 26.28 & 2.072 & 0.9979 \\
\hline
\end{tabular}

equations for the $\mathrm{Cr}$ (III) concentrations of 200 and $400 \mathrm{mg} \mathrm{L}^{-1}$ at 30,40 , and $50{ }^{\circ} \mathrm{C}$ were determined and are shown in Table 2. The correlation coefficients for the pseudo-second order are higher than 0.995 for all systems. This suggests that the sorption system is not a first-order process and that a pseudo-second-order model can be considered. This latter model is based on the assumption that the rate-limiting step may be chemisorption, involving valence forces through sharing or exchange of electrons between adsorbent and adsorbate (Ho and McKay, 1999). The results of Table 2 indicate that $k_{2}, V_{o}$, and $q_{e}$ vary with the initial $\mathrm{Cr}$ (III) concentration. For the pseudo-second-order model, the rate constant decreases with increasing initial $\mathrm{Cr}(\mathrm{III})$ concentration, whereas the initial adsorption rate increases with increasing initial $\mathrm{Cr}$ (III) concentration. For the pseudo-second-order model, both rate constant and initial adsorption rate increase significantly with increasing

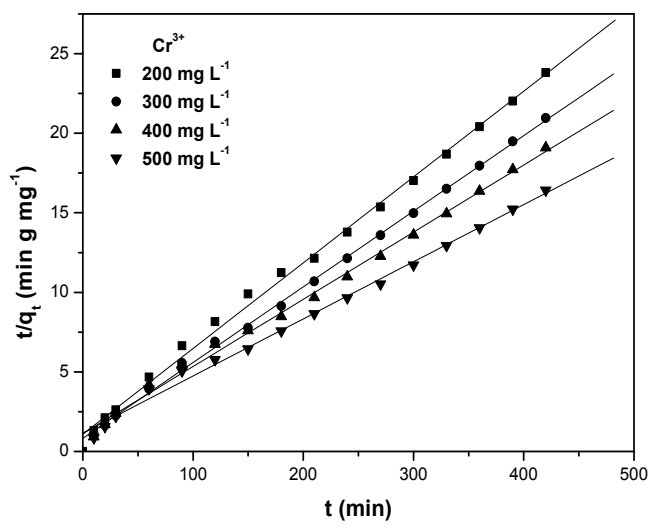

Figure 4. Pseudo-second-order plot of $\mathrm{Cr}$ (III) adsorption kinetics by RS at different temperatures and initial chromium concentration of $200 \mathrm{mg} \mathrm{L}^{-1}$. temperature from 30 to $50{ }^{\circ} \mathrm{C}$. This result may be interpreted as an indication of some specific interaction between the solid adsorbent and chromium ions.

To evaluate the activation energy of this adsorption process, the dependence of the pseudo-second order rate constant on temperature was expressed in terms of the Arrhenius equation:

$$
k=A e^{-E a / R T}
$$

Where $k$ is the rate constant as a function of temperature $T(\mathrm{~K}), A$ is the frequency factor, $R$ is the universal gas constant $\left(8.314 \mathrm{~J} \mathrm{~mol}^{-1} \mathrm{~K}^{-1}\right)$ and $E a$ $\left(\mathrm{kJ} \mathrm{mol}^{-1}\right)$ is the activation energy for the adsorption process. The magnitude of activation energy can indicate the type of sorption. The activation energy for physical adsorption is usually not higher than $4.2 \mathrm{~kJ} \mathrm{~mol}^{-1}$, since the forces involved are weak. Chemical adsorption is specific and involves forces much stronger than physical adsorption. So the activation energy for chemical adsorption is of the same magnitude as the heat of chemical reactions. Two kinds of chemical adsorption are encountered, namely, activated and non-activated, the latter being less frequent. Activated chemical adsorption means that the rate varies with temperature according to a finite activation energy (between 8.4 and $83.7 \mathrm{~kJ} \mathrm{~mol}^{-1}$ ) in the Arrhenius equation. In non-activated chemical adsorption, chemisorptions occur very rapidly, suggesting that the activation energy approaches zero (Smith, 1981). The activation energy can be obtained from the slope of the plot of In $k$ versus $1 / T$ (Figure not shown) and was found to be $26.22 \mathrm{~kJ} \mathrm{~mol}^{-1}$. This value is an indication that the adsorption process involves chemical forces. 


\subsection{Adsorption isotherms}

The equilibrium adsorption isotherm is important in order to describe the interactive behavior between solutes and adsorbent and in the design of the adsorption systems. The widely used Langmuir isotherm (Langmuir, 1916) has found successful applications in many real sorption processes. It can be expressed as:

$q_{e}=\frac{q_{m} b C_{e}}{1+b C_{e}}$

This, in linearized form, can be written as:

$\frac{C_{e}}{q_{e}}=\frac{1}{q_{m} b}+\frac{C_{e}}{b}$

where $C_{e}$ is the solution concentration at equilibrium ( $\left.\mathrm{mg} \mathrm{L}^{-1}\right), q_{e}$ is the amount adsorbed at equilibrium ( $\mathrm{mg} \mathrm{g}^{-1}$ ), and $q_{m}$ and $b$ are Langmuir constants related to maximum adsorption capacity (mg $\mathrm{g}^{-1}$ ) and adsorption energy $\left(\mathrm{L} \mathrm{mg}^{-1}\right)$, respectively. A plot of $C_{e} / q_{e}$ versus $C_{e}$ over the entire concentration range produces a straight line, which is an indication of the applicability of the Langmuir isotherm for the system under consideration.

The Freundlich isotherm describes reversible adsorption and is not restricted to the formation of a monolayer. This model assumes that different sites with several adsorption energies are involved in the adsorption process. The Freundlich isotherm can be expressed as:

$q_{e}=K_{F} C_{e}^{1 / n}$

A linear form of the Freundlich expression can also be obtained as:

$\log q_{e}=\log K_{F}+\frac{1}{n} \log C_{e}$

where $K_{F}$ and $n$ are the Freundlich constants related to adsorption capacity and adsorption intensity, respectively (Pollard et al., 1991). The intercept and the slope of the linear plot of $\ln q_{e}$ versus $\operatorname{In} C_{e}$ at given experimental conditions provide the values of $K_{F}$ and $1 / n$, respectively.

The linearized Langmuir and Freundlich adsorption isotherms obtained at 30,40 and $50{ }^{\circ} \mathrm{C}$ are shown in Figures 5 and 6, respectively. The plots in Figure 5 demonstrate that the Langmuir equation provides an accurate description of the experimental data, which is further confirmed by the high values of the correlation coefficient (Table 3). In general, the Langmuir model fitted the results slightly better than the Freundlich model, since all $R^{2}$ values are higher than 0.98 . This suggests that the adsorption of $\mathrm{Cr}$ (III) ions by RS is of monolayertype and is in accordance with the observation that the adsorption from an aqueous solution usually forms a layer on the adsorbent surface (Mattson and Mark, 1971). It is also observed that the values of Langmuir constants, $b$ and $q_{m}$, increased with increasing temperature, i.e., the adsorption capacity and intensity are enhanced at higher temperatures, suggesting a chemical interaction

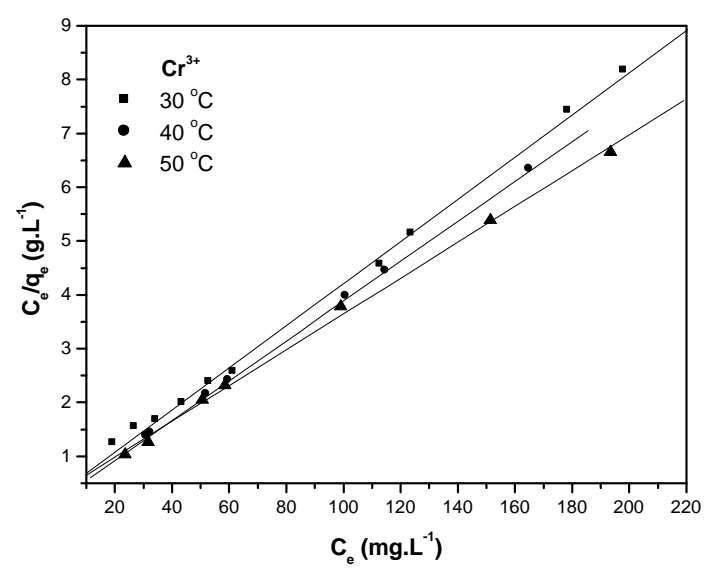

Figure 5. Linearized Langmuir isotherms obtained from $\mathrm{Cr}$ (III) adsorption by RS.

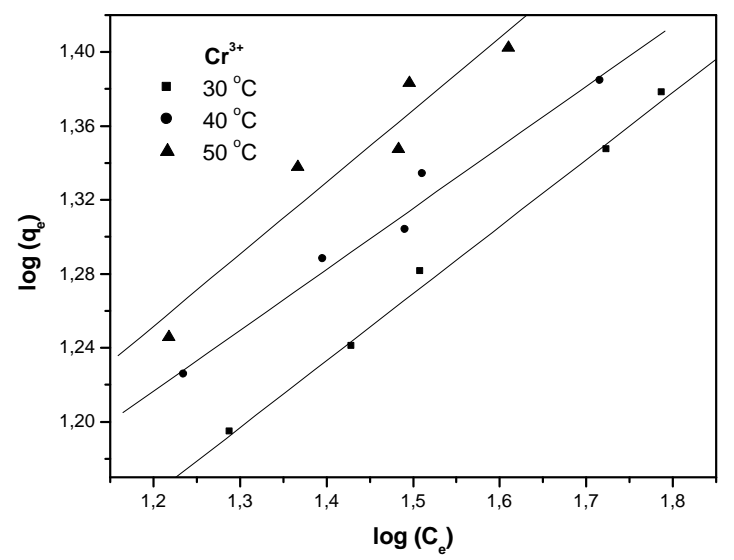

Figure 6. Linearized Freundlich isotherms obtained from $\mathrm{Cr}$ (III) adsorption by RS. 
Table 3. Correlation coefficients and parameters for Langmuir and Freundlich isotherms of $\mathrm{Cr}$ (III) adsorption by RS.

\begin{tabular}{ccccccc}
\hline $\mathbf{T}\left({ }^{\circ} \mathbf{C}\right)$ & \multicolumn{2}{c}{ Langmuir Constants } & \multicolumn{3}{c}{ Freundlich constants } \\
\cline { 2 - 7 } & $\boldsymbol{b}\left(\mathrm{L} \mathrm{mg}^{-1}\right)$ & $\boldsymbol{q}_{\boldsymbol{m}}\left(\mathbf{m g ~ g}^{-1}\right)$ & $\boldsymbol{R}^{\mathbf{2}}$ & $\boldsymbol{K}_{\boldsymbol{F}}\left(\mathbf{m g ~ g}^{-1}\right)$ & $\boldsymbol{N}$ & $\boldsymbol{R}^{\mathbf{2}}$ \\
\hline 30 & 0.0900 & 25.23 & 0.9968 & 5.3348 & 2.73 & 0.9621 \\
40 & 0.1070 & 27.68 & 0.9974 & 4.1900 & 2.06 & 0.9810 \\
50 & 0.1410 & 30.09 & 0.9980 & 6.5196 & 2.71 & 0.8910 \\
\hline
\end{tabular}

between adsorbent and adsorbate. As seen in Table 3, the monolayer maximum adsorption capacity $\left(q_{m}\right)$ was $30.09 \mathrm{mg} \mathrm{g}^{-1}$ at the optimum $\mathrm{pH}$ (5.5) and temperature $\left(50^{\circ} \mathrm{C}\right)$. The increase in the equilibrium adsorption capacity of $\mathrm{Cr}(\mathrm{III})$ with temperature indicates that higher temperatures favor $\mathrm{Cr}(\mathrm{III})$ removal by adsorption on RS.

Table 4. Equilibrium parameter, $R_{L}$, values.

\begin{tabular}{cccc}
\hline$C_{0}$ & \multicolumn{3}{c}{ Temperature $\left({ }^{\circ} \mathrm{C}\right)$} \\
\cline { 2 - 4 }$\left(\mathrm{mg} \mathrm{g}^{-1}\right)$ & $\mathbf{3 0}$ & $\mathbf{4 0}$ & $\mathbf{5 0}$ \\
\hline 200 & 0.052 & 0.045 & 0.034 \\
300 & 0.036 & 0.030 & 0.023 \\
400 & 0.027 & 0.023 & 0.017 \\
500 & 0.022 & 0.018 & 0.014 \\
\hline
\end{tabular}

The essential features of Langmuir's isotherms can be expressed in terms of a dimensionless constant separation factor or equilibrium parameter, $R_{L}$, which is defined by the following relationship (Hall et al., 1966):

$$
R_{L}=\frac{1}{1+b C_{o}}
$$

where $C_{o}$ is the initial metal ion $\mathrm{Cr}$ (III) concentration ( $\mathrm{mg} \mathrm{L}^{-1}$ ) and $b$ is Langmuir's constant. The value of $R_{L}$ indicates whether the isotherm is irreversible $\left(R_{L}\right.$ $=0)$, favorable $\left(0<R_{L}<1\right)$, linear $\left(R_{L}=1\right)$, or unfavorable $\left(R_{L}>1\right)$. The $R_{L}$ values for $\mathrm{Cr}(\mathrm{III})$ adsorption at different temperatures and concentrations are given in Table 4. These values indicate that the adsorption is more favorable at higher initial chromium concentrations. This indicates that the adsorption of $\mathrm{Cr}$ (III) onto RS is feasible at the concentrations studied (Erdem and Ozverdi, 2005; Lin and Juang, 2002).
Table 5. Adsorption maximum capacities of this work and the literature.

\begin{tabular}{|c|c|c|}
\hline Adsorbent & $\begin{array}{c}q_{m}\left(\mathrm{mg} \mathrm{g}^{-}\right. \\
\left.{ }^{1}\right)\end{array}$ & Reference \\
\hline Bark & 19.45 & $\begin{array}{c}\text { Randall et al., } \\
1974\end{array}$ \\
\hline Zeolite & 26.00 & Leppert, 1990 \\
\hline Retorted Shale & 30.09 & This work \\
\hline $\begin{array}{l}\text { Activated } \\
\text { carbon }\end{array}$ & 43.46 & $\begin{array}{l}\text { Lyubchik et al., } \\
2004\end{array}$ \\
\hline Peat & 76.00 & $\begin{array}{c}\text { Kertman et al., } \\
1993\end{array}$ \\
\hline Chitosan & 92.00 & $\begin{array}{c}\text { McKay et al., } \\
1989\end{array}$ \\
\hline
\end{tabular}

Table 6. Thermodynamic parameters of $\mathrm{Cr}(\mathrm{III})$ adsorption by RS.

\begin{tabular}{ccccc}
\hline $\begin{array}{c}\mathrm{T} \\
\left({ }^{\circ} \mathrm{C}\right)\end{array}$ & $\ln b$ & $\begin{array}{c}\Delta G^{\circ} \\
\left(\mathrm{kJ} \mathrm{mol}^{-1}\right)\end{array}$ & $\begin{array}{c}\Delta H^{\circ} \\
\left(\mathrm{kJ} \mathrm{mol}^{-1}\right)\end{array}$ & $\begin{array}{c}\Delta S^{\circ} \\
\left(\mathrm{J} \mathrm{mol}^{-1} \mathrm{~K}^{-1}\right)\end{array}$ \\
\hline 30 & 8.451 & -21.30 & & \\
40 & 8.623 & -22.45 & 18.62 & 131.59 \\
50 & 8.899 & -23.91 & & \\
\hline
\end{tabular}

A comparison of the maximum capacity, $b$, of RS with other adsorbents reported in the literature is given in Table 5. Differences of metal uptake are due to the properties of each adsorbent such as structure, functional groups, and surface areas. The adsorption capacity of RS was relatively high when compared with bark and zeolite. However, the adsorption capacity is much lower than some sorbents of organic origin, such as activated carbon, peat, and chitosan. The capacity of 
chitosan is almost 21 times higher than RS; however, since chitosan is nonporous and soluble in acidic solutions, it must be chemically modified in order to improve its sorption capacity.

\subsection{Thermodynamic studies}

Thermodynamic parameters such as change in free energy $\left(\Delta G^{\circ}\right)$, enthalpy $\left(\Delta H^{\circ}\right)$, and entropy $\left(\Delta S^{\circ}\right)$ for the adsorption process were determined using the following equations (Boonamnuayvitaya et al., 2004):

$\Delta G^{o}=-R T \ln b$

$\ln b=\frac{\Delta S^{0}}{R}-\frac{\Delta H^{0}}{R T}$

where $R$ is the ideal gas constant, $T$ is the solution temperature (K), and $b$ is Langmuir's constant. The slope and intercept of van't Hoff plots of $\ln b$ versus $1 / T$ were used to determine $\Delta H^{\circ}$ and $\Delta S^{\circ}$. These results are listed in Table 6 . The negative values of $\left(\Delta G^{\circ}\right)$ indicate that the adsorption of $\mathrm{Cr}(\mathrm{III})$ onto RS is spontaneous. The positive value of $\left(\Delta H^{\circ}\right)$ shows that the adsorption is an endothermic process. The positive value of $\left(\Delta S^{\circ}\right)$ indicates random increase at the solid-solution interface during the adsorption of $\mathrm{Cr}$ (III) onto RS.

\section{CONCLUSIONS}

Based on the physicochemical and batch adsorption experiments, it can be concluded that RS is effective in removing $\mathrm{Cr}(\mathrm{III})$ from aqueous solutions. The Langmuir equation confirms the equilibrium isotherm for the three temperatures and the entire concentration range studied. However, fitting the isotherm data with the Freundlich equation also yields a good correlation coefficient. The adsorption capacity increases with increasing temperature. The positive enthalpy value of the process shows that $\mathrm{Cr}$ (III) adsorption onto RS is endothermic, although spontaneous, and the kinetic studies suggest that adsorption involves activated or chemisorption processes.

\section{ACKNOWLEDGMENTS}

The authors would like to thank the National Petroleum Agency (ANP-Brazil) and the Petrobras Research Center (CENPES).

\section{REFERENCES}

Aksu, Z. Determination of the equilibrium, kinetic and thermodynamic parameters of the batch biosorption of nickel(II) ions onto Chlorella vulgaris. Process Biochemistry, v. 38 , p. 89-99, 2002.doi:10.1016/S0032-9592(02)00051-1

Al-Qodah, Z. Adsorption of dyes usin shale oil ash. Water Research, v. 34, p. 4295-4303, 2000. doi:10.1016/S0043-1354(00)00196-2

Boonamnuayvitaya, V.; Chaiya, C.; Tanthapanichakoon, W. and Jarudilokkul, S. Removal of heavy metals by adsorbent prepared from pyrolyzed coffee residues and clay. Separation and Purification Technology, v. 35, p.11-22, 2004. doi:10.1016/S1383-5866(03)00110-2

Brown, P. A.; Gill, S. A.; Allen, S. J. Metal Removal from wastewater using peat. Water Research, v. 34, p. 3907-3916, 2000. doi:10.1016/S0043-1354(00)00152-4

Celis, R.; Hermosin, M. C. and Cornejo, J. Heavy metal adsorption by functionalized clays. Environmental Science Technology, v. 34, p. 45934599, 2000. doi:10.1021/es000013c

Cooper, C.; Jiang, J.Q.; Ouki, S.; Singh, S.P.; Ma, Q.Y.; Harris, W.G. Heavy metal interactions with phosphatic clay: sorption and desorption behavior. Journal Environmental Quality, v. 30, p. 19611968, 2001. doi:10.2134/jeq2001.1961

Dabrowski, A.; Hubicki, Z.; Podko, P.; Robens, E. Selective removal of the heavy metal ions from waters and industrial wastewaters by ion-exchange method. Chemosphere, v. 56, p. 91-106, 2004. doi:10.1016/j.chemosphere.2004.03.006

ElShafey, E.I.; Cox, M.; Pichugin, A.A.; Appleton, Q. Application of a carbon sorbent for the removal of cadmium and other heavy metal ions from aqueous solution. Journal of Chemistry Technology and Biotechnology, v. 77, p. 429 - 436, 2002. doi:10.1002/jctb.577

Erdem, M.; Ozverdi, A. Lead adsorption from aqueous solution onto siderite. Separation and Purification Technology, v. 42, p. 259-264, 2005. doi:10.1016/i.seppur.2004.08.004 
Hall, K. R.; Eagleton L.C.; Acrivos, A.; Vermeulen, T. Pore and solid diffusion kinetics in fixed bed adsorption under constant pattern condition. Industrial \& Engineering Chemistry Fundamentals v. 5, p. 212-219, 1966. doi:10.1021/i160018a011

Ho, Y. S.; McKay, G. Pseudo-second order model for sorption processes. Process Biochemistry, v. 34, p. 451-465, 1999. doi:10.1016/S0032$\underline{\text { 9592(98)00112-5 }}$

Kertman, S.V.; kertman, G.M.; Chibrikova, Z.H.S. Peat as a heavy metal sorbent. Journal of Applied Chemistry, v. 66, p. 465-466, 1993.

Khraisheh, M.A.M.; Al-degs, Y.S.; Mcminn, W.A.M. Remediation of wastewater containing heavy metals using raw and modified diatomite. Chemistry Engineering Journal, v. 99, p.177-184, 2004. doi:10.1016/j.cej.2003.11.029

Langmuir, I. The constitution and fundamental properties of solids and liquids. Journal of American Chemical Society, v.38, p. 2221-2295, 1916. doi:10.1021/ja02268a002

Leppert, D. Heavy metal sorption with clinoptilolite zeolite: alternatives for treating contamined soil and water. Mining Engineering, v. 46, p. 604-608, 1990.

Lin, S.H.; Juang, R.S. Heavy metal removal from water by sorption using surfactant-modified montmorillonite. Journal of Hazardous Materials, v. 92 , p. 315-326, 2002. doi:10.1016/S03043894(02)00026-2

Low, K.S.; Lee, C. K.; Liew, S.C. Sorption of cadmium and lead from aqueous solutions by spent grain. Process Biochemistry, v. 36, p. 59-64, 2000. doi:10.1016/S0032-9592(00)00177-1
Lyubchik, S.I.; Lyubchik, A.I.; Galushko, O.L.; Tikhonova, L.P.; Vital, J.; Fonseca, I. M.; Lyubchik, S.B. Kinetics and thermodynamics of the $\mathrm{Cr}(\mathrm{III})$ adsorption on the activated carbon from comingled wastes. Colloids and Surfaces A: Physicochemistry Engineering Aspects, v. 242, p.151-158, 2004. doi:10.1016/j.colsurfa.2004.04.066

Mattson, J. S. and Mark, H. B. Activated carbons: Surface Chemistry and adsorption from solution, New York, Marcel Dekker, 1971. 237 p.

McKay, G.; Blair, H.S.; Findon, A. Equilibrium studies for the sorption of metal ion onto chitosan. Industrial Journal of Chemistry A, v. 28 , p. 356360, 1989.

Pollard, S.J.T.; Sollars, C.J.; Perry, R.A low cost adsorbent from spent bleahing earth in the selection of an activation procedure. Journal of Chemistry Technology and Biotechnology, v. 50, p. 265-275, 1991. doi:10.1002/jctb.280500211

Shukla, A.; Zhang, Y; Dubey, P.; Margrave, J.L.; Shukla, S.S. The role of sawdust in the removal of unwanted materials from water. Journal of Hazardous Materials, v. 95, p. 137-152, 2002. doi:10.1016/S0304-3894(02)00089-4

Smith, J.M. Chemical engineering kinetics, Singapore, McGraw-Hill, $3^{\text {rd }}$ edition, $1981.676 \mathrm{p}$.

Taty-costodes, V.C.; Fauduet, H.; Porte, C.; Delacroix, A. Removal of $\mathrm{Cd}(\mathrm{II})$ and $\mathrm{Pb}$ (II) ions, from aqueous solutions, by adsorption onto sawdust of Pinus sylvestris. Journal of Hazardous Materials B, v. $105, \quad$ p.121-142, 2003. doi:10.1016/i.jhazmat.2003.07.009

Randall, J.M.; Bermann, R.L.; Garret, V.; Waiss, A.C. Use of bark to remove heavy metals ions from waste solutions. Forest products Journal, v. 24, p. 80-84, 1974. 